\title{
Quality characteristics and retrogradation analysis of sponge cake added with freeze dried Peucedanum japonicum powder
}

\author{
Hee Nam Jung* \\ Department of Food \& Cooking Science, Sunchon National University, Suncheon 57922, Korea
}

\section{동결건조 방풍 분말을 첨가한 스펀지케이크의 품질 특성 및 노화도 분석}

\author{
정희남 \\ 순천대학교 생명산업과학대학 조리과학과
}

\begin{abstract}
The quality characteristics and retrogradation analysis of sponge cakes added with different ratios (i.e., $0,6,12$, 18 and $24 \mathrm{wt} \%$ ) of freeze dried Peucedanum japonicum powder (FDPP). The specific gravity of the batter and the baking-loss rate of the sponge cake were found to increased significantly upon increasing to amount of FDPP. The lightness (L) and yellowness (b) values also increased. In addition, the specific volume and volume index were the highest in 12\% FDPP group. Furthermore, in the presence of FDPP, the symmetry index was good in the range of $-0.01-0.15$, and the uniformity index was low, while the hardness and chewiness increased upon the addition of FDPP. During storage, the inhibition effect of retrogradation in the sponge cake was ranged from of 6 to $18 \%$, and the acceptance test indicated that the addition of FDPP in quantities up to $12 \%$ did not cause a negative effect on the sensory attributes. The obtained results therefore suggested that sponge cakes prepared using 12\% FDPP exhibit superior quality characteristics, retrogradation results, and sensory properties.
\end{abstract}

Key words : Peucedanum japonicum, sponge cake, quality characteristics, retrogradation

서 론

방풍(Pencedanum japonicum Thunb.)은 미나리과의 다년 생 초본식물로, 식방풍, 갯기름나물이라고도 불리고, 전 남, 전북, 경북, 충남 등에서 재배되며, 전라남도 여수, 고흥 지역이 전국 생산량의 대부분을 차지하고 있다(Son 등, 2013). 최근에는 건강한 먹거리에 대한 관심이 높아지면서 기능성 식재료로 인기를 얻고 있는 방풍은 시설재배를 통하여 겨울철에도 상시로 수확되고 있다. 방풍의 뿌리부 분은 발한, 해열, 거담 및 관절과 근육의 통증을 완화시키 는 한약재로 쓰이고, 어린 잎과 줄기는 쌈이나 나물로 소비 되며, 수시로 섭취하기 위한 방법으로는 장아찌가 주로
이용되고 있다(Son 등, 2014). 방풍은 여러 연구들에서 면 역효과(Kang 등, 2013), 항산화활성(Kim 등, 2009; Son 등, 2013), 대장염 완화 효과(Jung 등, 2014) 등의 생리활성이 우수한 약용식물로 식품소재로서의 활용이 기대되는 작 물이다. 방풍을 식품에 활용한 연구로는 방풍분말을 이용 한 양갱(Lee 등, 2018), 쿠키(Cha와 Lee, 2016), 떡류(Choi와 Cho, 2018)가 보고된 바 있으나, 상업화되지 못하고 있는 실정으로 다양한 식품 분야에서 연구될 필요성이 있다. 현대사회의 생활패턴이 빠르게 변화하고 있고, 식생활 이 서구화되어감에 따라 간편하게 섭취할 수 있는 베이커 리 제품들의 소비가 꾸준히 증가하고 있다(Zhang 등, 2017). 달걀의 기포성을 이용한 스편지케이크는 글루텐

\footnotetext{
*Corresponding author. E-mail : hnjung@sunchon.ac.kr, Phone : +82-61-750-3690, Fax : +82-61-750-3690

Received 15 November 2019; Revised 04 December 2019; Accepted 19 December 2019.

Copyright (c) The Korean Society of Food Preservation.

This is an Open Access article distributed under the terms of the Creative Commons Attribution Non-Commercial License (http://creativecommons.org/licenses/by-nc/4.0) which permits unrestricted non-commercial use, distribution, and reproduction in any medium, provided the original work is properly cited.
} 
함량의 영향이 적고, 부재료의 첨가가 용이한 베이커리제 품으로(Park 등, 2008; Kim 등 2014), 형태와 부재료에 따라 다양한 제품으로 변형이 가능하고, 대량생산이 가능하고 소비량 또한 높은 베이커리 제품 중 하나이다. 선행연구로 는 구기자(Shin 등, 2015), 나문재(An 등, 2016), 다시마 (Lim, 2012), 레몬그라스(Ju 등, 2016), 부추(Cho, 2010) 등 기능성 식재료를 첨가한 스펀지케이크에 관한 연구가 보 고되었다. 최근 건강에 대한 관심이 증가되면서 베이커리 산업에서도 기능성을 강조한 제품들이 시판되고 있으며, 생리활성이 있는 식품성 소재들을 첨가한 제빵제품들이 연구되고 있다. 이와 관련된 연구로 아마씨(Park 등, 2017), 양배추(Kim과 Kim, 2017), 석류껍질(Zhang 등, 2017), 녹차 (Lee와 Hwang, 2016), 라디치오(O 등, 2015), 아스파라거스 (Jang 등, 2015)을 첨가한 스펀지케이크의 항산화 특성에 관한 연구들이 보고되었으나, 방풍분말을 활용한 연구는 전무하다.

스펀지케이크는 빵에 비해 글루텐의 영향이 적어 부재 료의 첨가가 용이하나, 대부분의 연구에서 첨가재료의 함 량이 높아질수록 스펀지케이크의 비용적은 감소하는 것 으로 보고되고 있으며, 기능성 천연재료를 첨가한 연구들 에서 첨가량에 따른 품질 특성, 관능적 특성 및 항산화 활성에 따라 최적첨가비율을 제시하였다. 양배추 분말을 첨가한 스펀지케이크(Kim과 $\mathrm{Kim}, 2017)$ 에 관한 연구에서 는 5-10\% 첨가가 적절하다고 하였고, 다시마 분말을 첨가 한 스펀지케이크 연구(Lim, 2012)에서는 물리적 특성 및 관능적 특성을 모두 만족시키는 첨가량은 3-5\%라고 제 시하여 첨가재료의 특성에 따라 최적첨가량은 상이하게 보고되었다. 방풍은 특유의 맛과 향을 가지고 있는 식물로 스펀지케이크의 제조 시 품질 특성 및 관능적 특성을 고려 한 최적첨가량을 제시할 필요가 있다.

따라서 본 연구에서는 쌈채소, 나물, 장아찌로 활용범위 가 제한되어 있던 방풍을 소비자들이 간편하게 이용할 수 있는 식사대용 식품 중 하나인 스펀지케이크에 활용하
기 위해 방풍 잎부분을 동결건조하여 스펀지케이크를 제 조하였다. 동결건조 방풍분말의 최적첨가량을 확인하기 위하여 스펀지케이크의 품질 특성, 노화도 및 관능검사 특성을 비교분석하였다.

\section{재료 및 방법}

\section{실험재료}

본 실험에서 사용된 방풍(Peucedanum japonicum)은 전 라남도 여수시 금오도에서 2018년 4월에 수확된 것을 구입 하여 사용하였다. 동결건조 방풍 분말의 제조는 방풍의 잎 부분을 3회 세척하여 동결건조기(OPR-FDT-8650, Operon, Gimpo, Gyeonggi, Korea)를 이용하여 동결건조한 후 분쇄 기(Dream Mill DM-150S, Furukawa, Japan)로 분쇄하여 60 mesh로 하여 이용하였다. 박력분(CJ Jeiljedang, Seoul, Korea), 달걀(Pulmuone, Seoul, Korea), 설탕(CJ Jeiljedang), 소금(CJ Jeiljedang), 대두유(CJ Jeiljedang)를 시중에서 구입 하여 사용하였다.

\section{스펀지케이크의 제조}

동결건조 방풍 분말을 첨가한 스펀지케이크의 배합은 Table 1과 같고, 케이크의 제조는 Yi 등(2001)의 방법을 변형하여 제조하였다. 동결건조 방풍 분말은 박력분 중량 의 $0 \%, 6 \%, 12 \%, 18 \%$ 및 $24 \%$ 를 대체하여 첨가하였고, 스펀지케이크의 제조는 공립법을 이용하였다. 즉, 전란, 설탕 및 소금을 반죽기(5KPM5E, Whirlpool Inc., Benton Harbor, MI, USA)에 넣고 교반하여 거품을 형성시킨 후, 체에 친 박력분과 동결건조 방풍 분말을 넣고 혼합한 후 대두유를 넣고 반죽을 완성하였다. 완성된 반죽을 $8 \mathrm{inch}$ 의 원형팬에 $350 \mathrm{~g}$ 씩 팬닝하여 $180^{\circ} \mathrm{C}$ 로 예열된 전기오븐 (CPC-102, Dae Yung machinery, Seoul, Korea)에서 25분간 구웠다. 완성된 스펀지케이크는 실온에서 1시간 동안 방냉 한 후 실험에 사용하였다.

Table 1. Formula for sponge cake with freeze dried Peucedanum japonicum powder

\begin{tabular}{|c|c|c|c|c|c|}
\hline \multirow{2}{*}{ Ingredients (g) } & \multicolumn{5}{|c|}{ Peucedanum japonicum powder (\%) } \\
\hline & 0 & 6 & 12 & 18 & 24 \\
\hline Peucedanum japonicum powder & 0 & 6 & 12 & 18 & 24 \\
\hline Wheat flour & 100 & 94 & 88 & 82 & 76 \\
\hline Whole egg & 180 & 180 & 180 & 180 & 180 \\
\hline Sugar & 120 & 120 & 120 & 120 & 120 \\
\hline Salt & 1 & 1 & 1 & 1 & 1 \\
\hline Soy bean oil & 20 & 20 & 20 & 20 & 20 \\
\hline
\end{tabular}




\section{반죽 비중, 반죽 수율 및 굽기손실률 측정}

스펀지케이크의 반죽 비중은 AACC method 10-15 (AACC, 2000$)$ 에 따라 측정하였다. 비중컵에 담은 물의 무게에 대한 케이크 반죽의 비로 나타내었다. 반죽 수율과 굽기손실률은 굽기 전의 반죽 중량과 구운 후의 스펀지케 이크의 중량의 차이를 이용하여 다음의 식에 의해 산출하 였다.

Batter yield $(\%)=\frac{\text { Weight of cake }}{\text { Weight of cake batter }} \times 100$

Baking loss rate $(\%)=$

Weight of cake batter - Weight of cake Weight of cake batter

\section{수분함량 및 비용적 측정}

스펀지케이크의 수분함량은 상압가열 건조법(AOAC, 1990)을 이용하여 측정하였다. 비용적은 스펀지케이크의 무게와 부피에 의해 계산되었고, 부피는 AACC method 10-05(AACC, 2000)에 따라 측정하였으며, 비용적은 중량 에 대한 부피의 비 $(\mathrm{mL} / \mathrm{g})$ 로 표시하였다.

\section{색도 측정}

스펀지케이크 crust와 crumb 부분의 색도는 표준백색판 (L: 92.42, a: 0.55, b: 3.18)으로 보정된 색차계(JC 801S, Color Techno System Co., Tokyo, Japan)를 사용하여 Hunter's values L, a, b 값을 측정하였다.

\section{외관 특성 측정}

스펀지케이크의 외관은 부피 지표(volume index), 대칭 성 지표(symmetry index) 및 균일성 지표(uniformity index) 를 AACC method 10-91(AACC, 2000)에 따라 측정하여
평가하였다. 즉, 스펀지케이크 중심부를 수직으로 절단한 후 Fig. 1 과 같은 방법으로 측정하여 다음의 계산식으로 각각의 값을 산출하였다.

Volume index $=\mathrm{A}+\mathrm{B}+\mathrm{C}$

Symmetry index $=2 \mathrm{~B}-\mathrm{A}-\mathrm{C}$

Uniformity index $=\mathrm{A}-\mathrm{C}$

\section{단면 및 내부구조 관찰}

스펀지케이크의 단면은 디지털카메라(Nikon, Tokyo, Japan), 내부 구조는 비디오현미경(SV-32, Sometech Co., Seoul, Korea)을 이용하여 관찰하였다.

\section{물성 측정}

스펀지케이크의 물성은 texture analyzer(TA-XT2i, Stable Micro System Co., Surrey, UK)를 이용하여 texture profile analysis(TPA)로 분석하였고, crumb 부분을 $20 \times 20 \times 20 \mathrm{~mm}$ 의 크기로 잘라 측정하였다. 측정 조건은 test speed: 1.0 $\mathrm{mm} / \mathrm{s}$, strain: $50 \%$, probe: $45 \mathrm{~mm}$ cylinder로 하였고, 측정 후 얻어진 force-distance curve로부터 경도(hardness), 탄력성 (springiness), 응집성(cohesiveness) 및 씹힘성(chewiness)을 구하였다.

\section{Avrami 방정식을 이용한 스펀지케이크의 노화도 분석}

스펀지케이크의 노화도 분석은 Zhang 등(2017)의 방법 을 이용하여 분석하였고, 제조된 방풍분말 스펀지케이크 는 $20^{\circ} \mathrm{C}$ 에서 3 일간 저장하면서 측정한 경도값을 이용하여 스펀지케이크의 저장 중 경도 변화를 Avrami 방정식에 적용하여 노화 특성을 분석하였다.

\section{경도의 변화로}

$\theta=e^{-k t^{n}}$

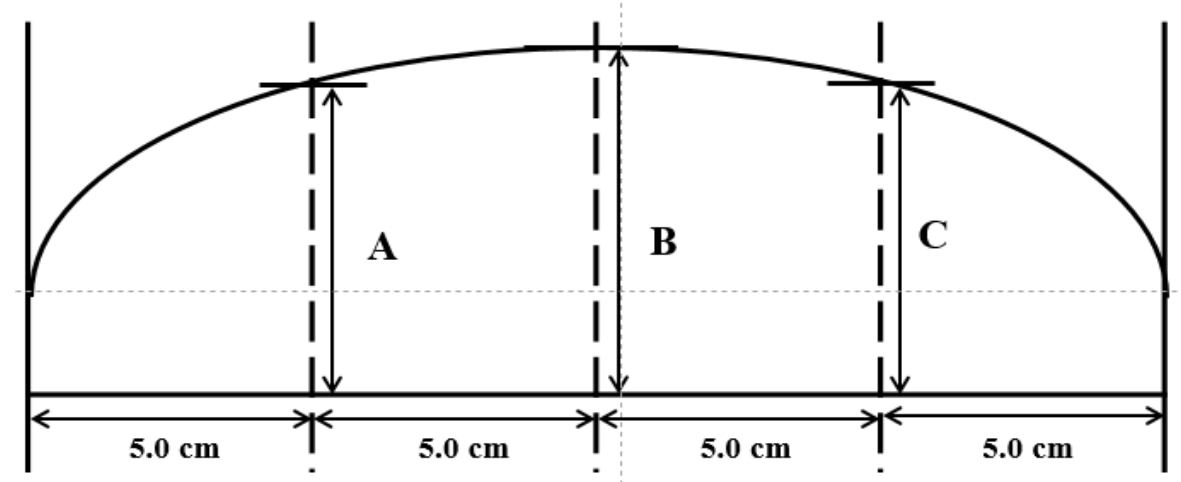

Fig. 1. Measurement of volume, symmetry and uniformity indexes of sponge cake with freeze dried Peucedanum japonicum powder. 
$\theta=$ 일정시간 후 결정화되지 않는 부분

$k=$ 속도상수(rate constant)

$n=$ 결정화 mode에 따라 1-4의 값을 갖는 Avrami 지수

$t=$ 저장시간

$\frac{E_{L}-E_{t}}{E_{L}-E_{O}}=e^{-k t^{n}}$

$E_{O}=$ 초기 $(0$ 시간 $)$ 의 경도

$E_{t}=\mathrm{t}$ 시간 경과 후의 경도

$E_{L}=$ 이론적으로 도달할 수 있는 최고의 경도

스펀지케이크의 이론적 최고 경도(limiting modulus)는 $5^{\circ} \mathrm{C}$ 에서 4 일간 저장 후 경도값으로 하였다.

식 (2)에서 자연로그와 상용로그를 취하면 다음과 같다.

$\ln \left(E_{L}-E_{t}\right) /\left(E_{L}-E_{O}\right)=-k t^{n}$

$\log \left[-\ln \left(E_{L}-E_{t}\right) /\left(E_{L}-E_{O}\right)\right]=\log k+n \log t$

Avrami 지수 $(n)$ 는 $\log$ 로 표시된 식 (4)에서 $\log \left[-\ln \left(E_{L}-\right.\right.$ $\left.\left.E_{t}\right) /\left(E_{L}-E_{O}\right)\right](\mathrm{y}$ 축 $)$ 을 $\log t(\mathrm{x}$ 축 $)$ 에 대하여 좌표를 나타낸 그래프의 기울기로 구하였다.

식 (2)에서 자연로그를 취하면 다음과 같다.

$$
\operatorname{In}\left(E_{L}-E_{t}\right)=-k t^{n}+\operatorname{In}\left(E_{L}-E_{O}\right)
$$

속도상수 $(k)$ 는 방정식 $(5)$ 로부터 $\operatorname{In}\left(E_{L}-E_{t}\right)$ 와 시간 $t$ 를 축으로 한 그래프의 기울기로 구하였으며, 시간상수 $(1 / k)$ 는 속도상수 $(k)$ 의 역수를 사용하였다.

\section{스펀지케이크의 관능검사}

동결건조 방풍 분말을 첨가한 스펀지케이크의 기호도 를 측정하기 위하여 38 명의 패널이 참여하였다. 제시된
시료의 크기는 $30 \times 30 \times 30 \mathrm{~mm}$ 이었고, 평가 항목은 color, flavor, taste, texture 및 overall acceptability이며, 각각의 특 성은 9점 척도로 평가하였다(1점은 '매우 좋지 않다', 9점 은 '매우 좋다')(Approval number: 1040173-201909-HR032-02).

\section{통계처리}

본 연구의 결과는 IBM SPSS Statistics(20, IBM Corp., Armonk, NY, USA)를 이용하여 분석하였으며, 평균, 표준 편차, 일원배치분산분석 및 Duncan의 다중범위 검정을 실 시하여 시료간의 유의적인 차이를 검증하였다.

\section{결과 및 고찰}

\section{반죽 비중, 반죽 수율 및 굽기손실률}

동결건조 방풍 분말을 첨가한 스펀지케이크의 반죽 비 중, 반죽 수율 및 굽기손실률을 측정한 결과는 Table 2 와 같다. 반죽 비중은 $24 \%$ 첨가구에서 0.52 로 가장 높았고, 대조구에서 0.44 로 가장 낮게 나타나 방풍 분말의 첨가량 이 증가할수록 반죽 비중은 증가하는 경향을 보였다. 케이 크 반죽의 비중은 달걀 거품의 형성 정도를 나타내는 지표 로서, 케이크의 부피와 텍스처에 영향을 미치는 중요한 요소이며, 일반적으로 반죽의 비중이 높으면 낮은 부피와 단단한 질감을 갖는다(Park 등, 2009; Song 등, 2017). 방풍 분말의 첨가량이 증가할수록 반죽 비중이 높아지는 양상 은 쑥 분말(Choi, 2016), 청경채 분말(Chung과 Kim, 2009), 솔잎 분말(Lee와 Lee, 2013)을 첨가한 스펀지케이크의 결 과와도 일치하였다. Shin 등(2007)은 첨가 분말이 달걀 거 품의 표면에 엉겨 붙어 기포 벽을 두껍게 함으로써 망상 구조 형성을 어렵게 하기 때문인 것으로 보고하였다. 굽기 손실률은 $24 \%$ 첨가구에서 $10.51 \%$ 로 가장 높았고, 대조구 에서 가장 낮았으며, 방풍 분말의 첨가량이 증가할수록 굽기손실률 또한 증가하는 경향을 보였으나, $6 \%, 12 \%$ 및 $18 \%$ 첨가구간에 유의한 차이는 없었다. 굽기손실률은 고 온에서 반죽을 굽는 과정에서 반죽이 팽창하고 반죽 내

Table 2. Specific gravity, batter yield and baking loss of sponge cake with freeze dried Peucedanum japonicum powder

\begin{tabular}{cccccc}
\hline \multirow{2}{*}{ Properties } & \multicolumn{5}{c}{ Peucedanm japonicum powder (\%) } \\
\cline { 2 - 6 } & 0 & 6 & 12 & 18 & 24 \\
\hline Specific gravity & $0.44 \pm 0.01^{1) \mathrm{d} 2)}$ & $0.46 \pm 0.01^{\mathrm{c}}$ & $0.48 \pm 0.01^{\mathrm{b}}$ & $0.49 \pm 0.01^{\mathrm{b}}$ & $0.52 \pm 0.02^{\mathrm{a}}$ \\
Batter yield (\%) & $90.70 \pm 0.21^{\mathrm{a}}$ & $90.20 \pm 0.18^{\mathrm{b}}$ & $90.33 \pm 0.17^{\mathrm{b}}$ & $90.07 \pm 0.20^{\mathrm{b}}$ & $89.50 \pm 0.16^{\mathrm{c}}$ \\
Baking loss (\%) & $9.30 \pm 0.21^{\mathrm{c}}$ & $9.80 \pm 0.18^{\mathrm{b}}$ & $9.67 \pm 0.17^{\mathrm{b}}$ & $9.93 \pm 0.20^{\mathrm{b}}$ & $10.51 \pm 0.16^{\mathrm{a}}$ \\
\hline
\end{tabular}

${ }^{1)}$ Values are Mean \pm SD $(n=5)$.

${ }^{2)}$ Mean \pm SD with different superscripts are significantly different $(\mathrm{p}<0.05)$ by Duncan's multiple test (row). 
수분이 수증기의 형태로 빠져 나가면서 발생하는 손실을 말하는데, 수분함량과 음의 상관관계를 보였다. 방풍분말 의 첨가량이 증가할수록 스펀지케이크 내부의 기공이 균 일하지 않고 커지는 경향을 보였고(Fig. 2), 크고 불균일한 기공들은 굽기 중 수분손실을 증가시켜 굽기손실률이 증 가한 것으로 생각된다. 매생이(Lee 등, 2007), 다시마(Lim, 2012), 레몬그라스(Ju 등, 2016)를 첨가한 스펀지케이크에 서도 본 연구와 같은 결과를 보고하였다.

\section{수분함량 및 비용적}

동결건조 방풍 분말을 첨가한 스펀지케이크의 수분함 량 및 비용적을 측정한 결과는 Table 3 과 같다. 수분함량은 대조구에서 $33.11 \%$ 로 가장 높았고, 방풍 분말 첨가구에서 $30.61-31.49 \%$ 로 방풍 분말의 첨가량이 증가할수록 유의 적으로 감소하였다. 이러한 결과는 밀가루의 수분함량은 $12 \%$ 내외, 방풍분말은 $7 \%$ 내외로 밀가루와 동결건조 방풍 분말의 수분함량의 차이에서 오는 결과로 생각되며, 나문 재(An 등, 2016), 레몬그라스(Ju 등, 2016), 솔잎 분말(Lee와 Lee, 2013)을 첨가한 스펀지케이크 연구에서도 첨가량에 따른 수분함량 감소를 보고하였다. 또, Lee 등(2009)은 흑 마늘 분말의 첨가에 따른 스펀지케이크의 수분함량 감소 는 흑마늘 분말의 수분함량뿐만 아니라, 흑마늘 분말의 첨가로 인한 밀가루 전분과 단백질의 수분흡수율의 차이
에서 오는 결과라고 하였다. 반죽 수율은 대조구에서 $90.70 \%$ 로 가장 높았고, 방풍 분말의 첨가량이 증가할수록 반죽 수율은 감소하는 경향을 보였으나, $6 \%, 12 \%$ 및 $18 \%$ 첨가구 간에 유의한 차이는 없었다. 비용적은 $12 \%$ 첨가구 에서 $3.30 \mathrm{~mL} / \mathrm{g}$ 으로 가장 높았고, 그 다음으로 $6 \%$, 대조구, $18 \%$ 순으로 각각 $3.22 \mathrm{~mL} / \mathrm{g}, 3.16 \mathrm{~mL} / \mathrm{g}, 3.00 \mathrm{~mL} / \mathrm{g}$ 이었으 며, $24 \%$ 첨가구에서 $2.78 \mathrm{~mL} / \mathrm{g}$ 으로 가장 낮았다. 여러 연구 에서 반죽의 비중이 낮을수록 높은 비용적을 갖는 것으로 보고되고 있었으나, 본 연구에서는 상이한 결과를 보였다. 이는 반죽의 비중과 더불어 방풍 분말의 첨가에 의해 굽기 후 냉각 단계에서 나타난 케이크의 꺼짐현상이 스펀지케 이크의 최종부피에 영향을 미쳤기 때문으로 생각된다. 방 풍 분말을 첨가하지 않은 대조구의 비중은 첨가구에 비하 여 높았으나, 대조구의 비용적은 냉각 중 부피 감소로 인하 여 $12 \%$ 첨가구에 비해 낮았고, $6 \%$ 첨가구와 유사한 수준 을 보여 $12 \%$ 이내의 방풍 분말 첨가는 부피에 긍정적인 영향을 줄 수 있을 것으로 사료된다. $\operatorname{Kim}(2003)$ 은 뽕잎 분말의 첨가량이 증가함에 따라 결합하는 수분의 양이 증가하고, 상대적으로 전분 호화에 사용되는 수분의 양은 감소하여 $20 \%$ 첨가구에서 부피 감소가 나타났다고 하여 적정량 이상의 첨가는 오히려 최종부피에 부정적인 영향 을 미친다고 하였고, 본 연구에서도 $18 \%$ 이상 첨가하였을 때 비용적이 급격하게 감소하는 경향을 보였다.
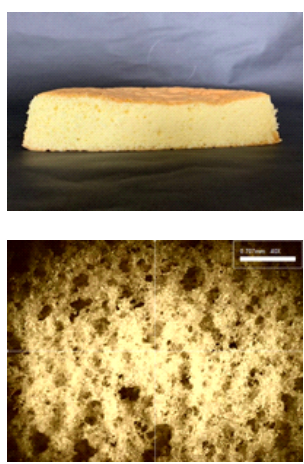

$0 \%$
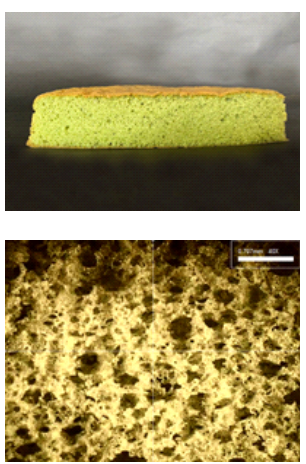

$6 \%$
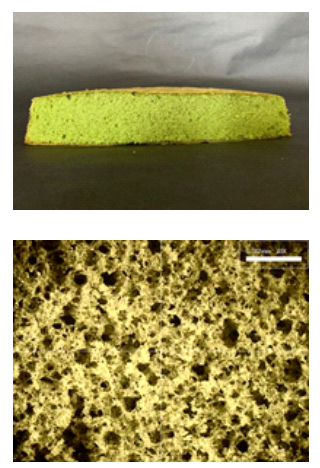

$12 \%$
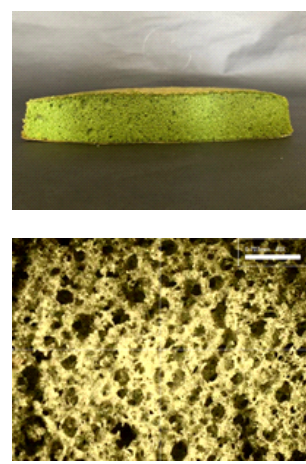

$18 \%$
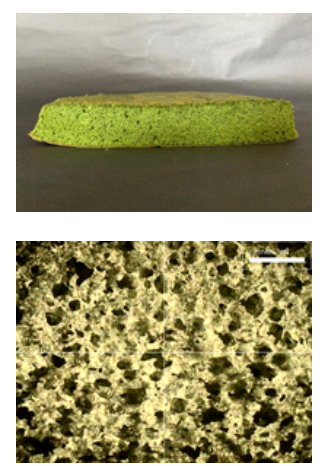

$24 \%$

Fig. 2. Cross section and internal structure of sponge cake with freeze dried Peucedanum japonicum powder.

Table 3. Moisture content and specific volume of sponge cake with freeze dried Peucedanum japonicum powder

\begin{tabular}{cccccc}
\hline \multirow{2}{*}{ Properties } & \multicolumn{5}{c}{ Peucedanm japonicum powder (\%) } \\
\cline { 2 - 6 } & 0 & 6 & 12 & 18 & 24 \\
\hline Moisture (\%) & $33.11 \pm 0.81^{\mathrm{a}}$ & $31.49 \pm 0.43^{\mathrm{b}}$ & $31.43 \pm 0.33^{\mathrm{b}}$ & $31.07 \pm 0.50^{\mathrm{bc}}$ & $30.61 \pm 0.38^{\mathrm{c}}$ \\
Specific volume $(\mathrm{mL} / \mathrm{g})$ & $3.16 \pm 0.17^{\mathrm{ab}}$ & $3.22 \pm 0.30^{\mathrm{ab}}$ & $3.30 \pm 0.16^{\mathrm{a}}$ & $3.03 \pm 0.12^{\mathrm{b}}$ & $2.78 \pm 0.10^{\mathrm{c}}$ \\
\hline
\end{tabular}

${ }^{1)}$ Values are Mean \pm SD $(\mathrm{n}=5)$.

${ }^{2)}$ Mean \pm SD with different superscripts are significantly different $(\mathrm{p}<0.05)$ by Duncan's multiple test (row). 
색도

동결건조 방풍 분말을 첨가한 스펀지케이크의 crust와 crumb 부분 색도를 측정한 결과는 Table 4 와 같다. L값은 crust와 crumb 모두 대조구에서 각각 $65.80,77.44$ 로 가장 높았고, 방풍 분말의 첨가량이 증가할수록 유의적으로 감 소하였다. Crust에서 a값은 첨가량이 증가할수록 유의적으 로 감소하는 경향을 보였으나, crumb에서는 일정한 경향 을 보이지 않았다. 황색도인 b값도 L값과 마찬가지로 crust 와 crumb 모두 대조구에서 각각 $18.05,17.99$ 로 가장 높았 고, 방풍 분말의 첨가량이 증가할수록 유의적으로 감소하 는 경향을 보였다. Crust와 crumb 모두에서 방풍 분말의 첨가량이 증가할수록 대체로 $\mathrm{L}$ 값 및 $\mathrm{b}$ 값이 모두 감소하였 고, crust의 a값 또한 감소하는 경향을 보여 어둡고 녹색을 띄는 것으로 나타났다. 스펀지케이크의 색도는 첨가재료 의 색에 의해 영향을 받으며, 부추(Cho, 2010), 쑥(Choi, 2016), 연잎(Song, 2013) 등을 이용한 스펀지케이크 연구에 서도 같은 결과를 보고하였다.

\section{외관 특성}

동결건조 방풍 분말을 첨가한 스펀지케이크의 부피 지 수(volume index), 대칭성 지수(symmetry index) 및 균일성 지수(uniformity index)를 측정한 결과는 Table 5 , 단면과 내부 구조의 사진은 Fig. 2 와 같다. 부피 지수는 $12 \%$ 첨가 구에서 12.82 로 가장 높았고, 그 다음으로 $6 \%$, 대조구, $18 \%$ 첨가구 순으로 각각 $12.66,12.41,11.91$ 이었으며, $24 \%$ 첨가 구에서 10.67로 유의적으로 낮았으며, 비용적과 유사한 경향을 보였다. 대칭성 지수는 케이크의 형태를 나타내는 값으로 음의 값은 중앙부분이 꺼진 형태, 0 에 가까울수록 중앙부분이 평평한 형태, 양의 값은 돔 형태를 나타낸다(O 등, 2017). 대칭성 지수는 $18 \%$ 첨가구에서 0.15 로 가장 높았고, 대조구에서 -0.46 으로 유의적으로 낮았으며, 방 풍 분말 첨가구에서 $-0.01-0.15$ 의 범위로 대조구에 비해 윗면이 평평하게 나타났다. 균일성 지수는 케이크 좌우의 치우친 정도를 나타내는 값으로(Choi 등, 2007), 대조구에 서 0.23 으로 가장 높게 나타나 방풍 분말 첨가구에 비하여 치우침의 정도가 크게 나타났고, 방풍 분말 첨가구에서 모두 0.02 로 낮은 값을 보였으며, 첨가량에 따른 유의적인 차이는 없었다. Fig. 2의 케이크의 단면 사진에서 보는 바와 같이, 대조구 스펀지케이크는 중앙부분이 약간 꺼진 형태 를 보였고, 첨가구에서는 대체로 평평한 형태를 보였으며, $18 \%$ 이상 첨가시 부피의 감소가 뚜렷하게 관찰되었다. 내부 구조의 사진에서 기공의 분포는 모든 시료에서 대체

Table 4. Color value of sponge cake with freeze dried Peucedanum japonicum powder

\begin{tabular}{ccccccc}
\hline \multirow{2}{*}{ Properties } & & \multicolumn{5}{c}{ Peucedanm japonicum powder (\%) } \\
\cline { 3 - 7 } & & 0 & 6 & 12 & 18 & 24 \\
\hline \multirow{2}{*}{ Crust } & $\mathrm{L}$ & $65.80 \pm 0.92^{1) \mathrm{a} 2)}$ & $57.65 \pm 0.79^{\mathrm{b}}$ & $50.77 \pm 1.10^{\mathrm{c}}$ & $47.48 \pm 1.61^{\mathrm{d}}$ & $45.87 \pm 0.21^{\mathrm{e}}$ \\
& $\mathrm{a}$ & $12.17 \pm 1.01^{\mathrm{a}}$ & $6.42 \pm 0.25^{\mathrm{b}}$ & $2.57 \pm 0.29^{\mathrm{c}}$ & $-3.93 \pm 0.15^{\mathrm{d}}$ & $-3.76 \pm 0.20^{\mathrm{d}}$ \\
& $\mathrm{b}$ & $18.05 \pm 0.96^{\mathrm{a}}$ & $12.12 \pm 1.21^{\mathrm{b}}$ & $4.58 \pm 1.39^{\mathrm{c}}$ & $-0.72 \pm 0.13^{\mathrm{d}}$ & $-3.05 \pm 0.10^{\mathrm{e}}$ \\
\hline \multirow{2}{*}{ Crumb } & $\mathrm{L}$ & $77.44 \pm 0.52^{\mathrm{a}}$ & $59.85 \pm 0.77^{\mathrm{b}}$ & $57.28 \pm 0.74^{\mathrm{c}}$ & $52.36 \pm 0.79^{\mathrm{d}}$ & $48.12 \pm 0.21^{\mathrm{e}}$ \\
& $\mathrm{a}$ & $1.40 \pm 0.07^{\mathrm{a}}$ & $-4.63 \pm 0.05^{\mathrm{e}}$ & $-4.43 \pm 0.15^{\mathrm{d}}$ & $-4.23 \pm 0.17^{\mathrm{c}}$ & $-3.92 \pm 0.01^{\mathrm{b}}$ \\
& $\mathrm{b}$ & $17.99 \pm 0.76^{\mathrm{a}}$ & $10.60 \pm 1.46^{\mathrm{b}}$ & $10.34 \pm 1.15^{\mathrm{b}}$ & $7.33 \pm 1.41^{\mathrm{c}}$ & $0.13 \pm 0.03^{\mathrm{d}}$ \\
\hline
\end{tabular}

${ }^{1)}$ Values are Mean $\pm \mathrm{SD}(\mathrm{n}=10)$

${ }^{2)}$ Mean \pm SD with different superscripts are significantly different $(\mathrm{p}<0.05)$ by Duncan's multiple test (row).

Table 5. Appearance characteristics of sponge cake with freeze dried Peucedanum japonicum powder

\begin{tabular}{cccccc}
\hline \multirow{2}{*}{ Properties } & \multicolumn{5}{c}{ Peucedanm japonicum powder (\%) } \\
\cline { 2 - 6 } & 0 & 6 & 12 & 18 & 24 \\
\hline Volume index & $12.41 \pm 0.37^{1) \mathrm{b} 2)}$ & $12.66 \pm 0.07^{\mathrm{ab}}$ & $12.82 \pm 0.05^{\mathrm{a}}$ & $11.91 \pm 0.12^{\mathrm{c}}$ & $10.67 \pm 0.18^{\mathrm{d}}$ \\
Symmetry index & $-0.46 \pm 0.05^{\mathrm{d}}$ & $-0.03 \pm 0.02^{\mathrm{c}}$ & $0.08 \pm 0.01^{\mathrm{b}}$ & $0.15 \pm 0.03^{\mathrm{a}}$ & $-0.01 \pm 0.00^{\mathrm{c}}$ \\
Uniformity index & $0.23 \pm 0.02^{\mathrm{a}}$ & $0.02 \pm 0.01^{\mathrm{b}}$ & $0.02 \pm 0.01^{\mathrm{b}}$ & $0.02 \pm 0.01^{\mathrm{b}}$ & $0.02 \pm 0.01^{\mathrm{b}}$ \\
\hline
\end{tabular}

${ }^{1)}$ Values are Mean \pm SD $(n=5)$.

${ }^{2)}$ Mean \pm SD with different superscripts are significantly different $(\mathrm{p}<0.05)$ by Duncan's multiple test (row). 
로 일정하였으나, 기공의 크기는 $12 \%$ 첨가구까지 대체로 작아지다가 이후로 첨가량이 증가할수록 부분적으로 커 지는 경향을 보였다. 이러한 결과는 첨가량에 따른 반죽의 비중과 굽기 중 팽창에 따른 기포의 유지력 등에 의한 결과로 $18 \%$ 이상 첨가 시 높은 비중과 굽는 과정 중 기공 내의 공기를 유지하지 못하고 붕괴되면서 기공끼리 합쳐 지는 현상에서 오는 결과로 생각된다.

\section{물성}

동결건조 방풍 분말을 첨가한 스펀지케이크의 물성을 측정한 결과는 Table 6 과 같다. 대조구 스펀지케이크의 경도는 $157.55 \mathrm{~g}$ 이었고, 방풍 분말을 첨가한 스펀지케이크 는 $196.47-322.54 \mathrm{~g}$ 의 범위로 방풍 분말의 첨가량이 증가 할수록 유의적으로 높게 나타났으며, $6 \%$ 와 $12 \%$ 첨가구 간에 유의한 차이는 없었다. 탄력성은 대조구에서 0.90 으 로 높았고, 방풍 분말 첨가구에서 $0.87-0.89$ 로 대조구에 비해 유의적으로 낮았다. Cho(2010)는 밀가루 대체 재료로 글루텐이 없는 분말 시료를 첨가하였을 때, 전분과 글루텐 의 열변성 조직이 약해져 케이크의 탄력성이 감소한다고 하였다. 응집성은 대조구에서 0.56 으로 가장 높았고, 첨가 구에서 0.51-0.55의 범위로 방풍 분말의 첨가량이 증가할 수록 유의적으로 낮았다. 응집성은 케이크의 내부에서 재 료들이 결착하려는 성질을 나타내며, 응집성이 낮은 케이 크는 균열되거나 부서지기 쉽다(Onyango 등, 2010). 씹힘
성은 $24 \%$ 첨가구에서 143.51 로 가장 높았고, 대조구에서 79.43 으로 유의적으로 낮았으며, 방풍 분말의 첨가량이 증가할수록 높아지는 경향을 보였다. 케이크의 물성은 수 분함량, 기공의 발달 정도 및 부피의 영향을 받으며, 기공 이 잘 발달하여 부피가 클수록 경도가 낮고 부드러운 것으 로 알려져 있다(Park 등, 2008). 여러 연구들에서 첨가량 증가에 따른 기공발달과 팽창 억제, 부피 감소 등으로 인하 여 스펀지케이크의 경도와 씹힘성은 증가하였고, 탄력성 과 응집성은 감소하였다고 보고되었다(Seo 등, 2015; Kim 과 Kim, 2017; Jang 등, 2018). 본 연구의 물성 측정 결과, 방풍 분말의 첨가량이 증가할수록 경도와 씹힘성은 증가 하고, 응집성은 감소하는 경향을 보였고, 이는 반죽의 비 중, 최종제품의 부피 및 수분함량 등 여러 요인들이 스펀지 케이크의 물성에 복합적으로 작용한 것으로 생각된다.

\section{노화도}

동결건조 방풍 분말을 첨가한 스펀지케이크를 $20^{\circ} \mathrm{C}$ 에 3 일간 저장하면서 측정한 경도값을 Avrami 방정식을 이용 하여 저장 중 스펀지케이크의 노화도를 분석한 결과는 Table 7과 같다. Avrami 지수 $(n)$ 는 결정핵 형성 시간 및 형성 속도에 따른 결정화 형태를 나타내고, 값이 작을수록 결정핵 형성이 지연되어 노화가 억제됨을 나타낸다(Song 등, 2017; Zhang 등, 2017). 대조구의 Avrami 지수(n)는 2.0327 이었고, $6 \%, 12 \%$ 및 $18 \%$ 첨가구는 각각 0.5958 ,

Table 6. Texture characteristics of sponge cake with freeze dried Peucedanum japonicum powder

\begin{tabular}{cccccc}
\hline & \multicolumn{5}{c}{ Peucedanm japonicum powder (\%) } \\
\cline { 2 - 6 } Properties & 0 & 6 & 12 & 18 & 24 \\
\hline Hardness (g) & $157.55 \pm 25.73^{1 \mathrm{~d} 2)}$ & $197.78 \pm 21.16^{\mathrm{c}}$ & $196.47 \pm 9.00^{\mathrm{c}}$ & $242.30 \pm 16.60^{\mathrm{b}}$ & $322.54 \pm 19.86^{\mathrm{a}}$ \\
Springiness & $0.90 \pm 0.02^{\mathrm{a}}$ & $0.89 \pm 0.01^{\mathrm{b}}$ & $0.88 \pm 0.02^{\mathrm{b}}$ & $0.89 \pm 0.02^{\mathrm{b}}$ & $0.87 \pm 0.01^{\mathrm{b}}$ \\
Cohesiveness & $0.56 \pm 0.02^{\mathrm{a}}$ & $0.55 \pm 0.01^{\mathrm{ab}}$ & $0.54 \pm 0.02^{\mathrm{b}}$ & $0.52 \pm 0.02^{\mathrm{c}}$ & $0.51 \pm 0.00^{\mathrm{d}}$ \\
Chewiness & $79.43 \pm 12.60^{\mathrm{d}}$ & $96.60 \pm 10.98^{\mathrm{c}}$ & $94.11 \pm 7.92^{\mathrm{c}}$ & $112.85 \pm 7.82^{\mathrm{b}}$ & $143.51 \pm 8.91^{\mathrm{a}}$ \\
\hline
\end{tabular}

${ }^{1)}$ Values are $\operatorname{Mean} \pm \mathrm{SD}(\mathrm{n}=7)$.

${ }^{2)}$ Mean \pm SD with different superscripts are significantly different $(\mathrm{p}<0.05)$ by Duncan's multiple test (row).

Table 7. Avrami exponent (n), rate constant $(k)$ and time constant (1/k) of sponge cake with freeze dried Peucedanum japonicum powder

\begin{tabular}{cccccc}
\hline \multirow{2}{*}{ Properties } & \multicolumn{5}{c}{ Peucedanm japonicum powder (\%) } \\
\cline { 2 - 5 } & 0 & 6 & 12 & 18 & 24 \\
\hline Avrami exponent $(n)^{1)}$ & 2.0327 & 0.5958 & 0.5475 & 0.8405 & 3.3856 \\
Rate constant $(k)^{2)}$ & $7.8 \times 10^{-3}$ & $3.1 \times 10^{-3}$ & $2.7 \times 10^{-3}$ & $1.1 \times 10^{-3}$ & $10.2 \times 10^{-3}$ \\
Time constant $(1 / k)$ & 128.21 & 322.58 & 370.37 & 909.09 & 98.04 \\
\hline
\end{tabular}

${ }^{1)}$ Values obtained from slop of plot $\log \left\{-\ln \left(E_{L}-E_{t}\right) /\left(E_{L}-E_{O}\right)\right\}$ vs $\log t$.

${ }^{2)}$ Values obtained from slop of plot $\ln \left(E_{L}-E_{t}\right)$ vs time. 
$0.5475,0.8405$ 이었고, $24 \%$ 첨가구는 3.3856 으로 급격히 증가하였다. 이는 대조구와 비교하여 방풍 분말 6-18\% 첨가구에서 결정화가 지연됨을 확인할 수 있었다. 시간상 수 $(1 / k)$ 는 속도상수 $(k)$ 의 역수이며, 노화의 진행속도를 보 여주는 값으로, 속도상수 $(k)$ 값이 작을수록 더 큰 시간상수 $(1 / k)$ 값을 갖게 되고, 이는 노화가 억제되어 최종노화까지 더 많은 시간이 소요됨을 나타낸다. 대조구의 시간상수 (1/k) 값은 128.21 이었고, 6-18\% 첨가구에서 322.28909.09로 대조구에 비해 더 큰 시간상수 $(1 / k)$ 값을 나타냈 으며, $24 \%$ 첨가구에서는 98.04 로 급격하게 감소하여 6 $18 \%$ 첨가 범위에서 노화억제 효과를 보였다. 식이섬유는 수분을 보유하려는 성질이 있어 저장 기간 동안 케이크의 경도 변화를 감소시켜 노화를 지연시키는 효과가 있는 것으로 보고되었다. 본 연구에서 방풍분말 첨가구에서 노 화가 지연되는 것은 방풍 분말에 함유되어 있는 식이섬유 때문인 것으로 사료된다.

\section{기호도}

동결건조 방풍 분말을 첨가한 스펀지케이크의 색 (color), 향미(flavor), 맛(taste), 질감(texture) 및 전체적인 기호도(overall acceptability)를 측정한 결과는 Table 8 과 같다. 색에 대한 기호도는 $12 \%$ 첨가구에서 6.68 로 유의적 으로 높았고, $6 \%$ 와 $24 \%$ 첨가구에서 낮은 기호도를 보였 다. 향미에 대한 기호도는 $6 \%$ 에서 6.63 으로 가장 높았고, 대조구와 $12 \%$ 첨가구에서 각각 $5.84,5.50$ 이었으며, $24 \%$ 첨가구에서 3.29 로 유의적으로 낮았다. 대조구에 비해 $6 \%$ 첨가구에서 향미에 대한 기호도가 높게 나타난 것은 방풍 분말의 첨가로 인해 달걀의 비린 향이 감소되었기 때문인 것으로 생각되며, $12 \%$ 이상 첨가 시에는 방풍의 독특한 향으로 인해 향미에 대한 기호도는 급격히 감소하였다. 맛에 대한 기호도는 대조구, $6 \%, 12 \%$ 첨가구에서 각각 $6.68,6.84,6.61$ 로 높은 기호도를 보였다. 질감에 대한 기호 도는 대조구에서 7.45 로 가장 높았고, $6 \%$ 와 $12 \%$ 첨가구에
서 각각 $6.84,6.79$ 이었으며, $24 \%$ 첨가구에서 4.55 로 질감 에 대한 기호도가 현저히 감소하였다. 전체적인 기호도는 $6 \%$ 첨가구에서 7.08 로 가장 높았고, 대조구, $12 \%, 18 \%$ 첨가구에서 각각 $6.53,6.08,6.00$ 이었으며, $24 \%$ 첨가구에 서 4.11로 가장 낮았다. 기호도 검사의 결과에서 전체적인 기호도는 $6 \%$ 첨가구에서 가장 높았으나, 색, 향미, 맛, 질감 및 전체적인 기호도를 종합하였을 때, 대조구와 비교하여 관능적 품질을 저해하지 않는 방풍 분말의 첨가 범위는 $12 \%$ 까지 가능할 것으로 사료된다.

\section{요 약}

본 연구에서는 식생활의 변화와 건강지향적인 식품에 대한 소비자의 요구로 생리활성이 높은 방풍을 이용하여 스펀지케이크를 제조하였다. 동결건조 방풍 분말을 6 $24 \%$ 첨가하여 반죽과 스펀지케이크의 품질 특성, 노화도 및 관능적 특성 분석을 통하여 최적첨가량을 제시하고자 하였다. 방풍 분말의 첨가량이 증가할수록 반죽비중과 굽 기손실률은 증가하였다. 비용적은 $12 \%$ 첨가구에서 유의 적으로 높았다. 색도 결과에서, $\mathrm{L}$ 값과 $\mathrm{b}$ 값은 방풍분말의 첨가량이 증가할수록 감소하였다. 스펀지케이크의 비용 적과 부피지수는 방풍 분말 $12 \%$ 첨가구에서 가장 높았다. 대칭성 지수는 방풍 분말 첨가구에서 $-0.01-0.15$ 의 범위 로 양호한 값을 보였고, 균일성 지수는 방풍 분말 첨가구에 서 모두 0.02 로 낮은 값을 보였다. 스펀지케이크의 경도는 대조구에서 $157.55 \mathrm{~g}$ 으로 가장 낮았고, 방풍분말의 첨가량 이 증가할수록 증가하였다. 저장기간 동안 경도값의 변화 를 통한 노화도를 분석한 결과, 6- $18 \%$ 첨가 범위에서 노화억제 효과를 보였다. 기호도 검사 결과에서, 대조구와 비교하였을 때 관능적 특성이 저해되지 않는 방풍 분말의 첨가 범위는 $12 \%$ 까지인 것으로 측정되었다. 본 실험의 결과를 기초로 하여 스펀지케이크의 제조에서 동결건조 방풍분말의 첨가는 $12 \%$ 가 적정할 것으로 사료된다.

Table 8. Sensory evaluation of sponge cake with freeze dried Peucedanum japonicum powder

\begin{tabular}{|c|c|c|c|c|c|}
\hline \multirow{2}{*}{ Properties } & \multicolumn{5}{|c|}{ Peucedanm japonicum powder (\%) } \\
\hline & 0 & 6 & 12 & 18 & 24 \\
\hline Color & $6.34 \pm 1.32^{1) \mathrm{ab} 2)}$ & $4.63 \pm 1.67^{\mathrm{c}}$ & $6.68 \pm 1.30^{\mathrm{a}}$ & $5.82 \pm 1.83^{\mathrm{b}}$ & $5.08 \pm 1.51^{\mathrm{c}}$ \\
\hline Flavor & $5.84 \pm 1.10^{\mathrm{b}}$ & $6.63 \pm 1.38^{\mathrm{a}}$ & $5.50 \pm 1.47^{\mathrm{b}}$ & $4.68 \pm 1.69^{c}$ & $3.29 \pm 1.45^{\mathrm{d}}$ \\
\hline Taste & $6.68 \pm 1.12^{\mathrm{a}}$ & $6.84 \pm 1.28^{\mathrm{a}}$ & $6.61 \pm 1.42^{\mathrm{a}}$ & $5.74 \pm 1.61^{\mathrm{b}}$ & $4.87 \pm 1.63^{\mathrm{c}}$ \\
\hline Texture & $7.45 \pm 0.76^{\mathrm{a}}$ & $6.84 \pm 1.50^{\mathrm{b}}$ & $6.79 \pm 1.17^{\mathrm{b}}$ & $6.11 \pm 1.31^{\mathrm{c}}$ & $4.55 \pm 1.39^{\mathrm{d}}$ \\
\hline Overall acceptability & $6.53 \pm 1.18^{\mathrm{b}}$ & $7.08 \pm 0.97^{\mathrm{a}}$ & $6.08 \pm 1.28^{\mathrm{bc}}$ & $6.00 \pm 0.93^{\mathrm{c}}$ & $4.11 \pm 1.11^{\mathrm{d}}$ \\
\hline
\end{tabular}

\footnotetext{
${ }^{1)}$ Values are Mean \pm SD $(n=38)$.
}

${ }^{2)}$ Mean \pm SD with different superscript are significantly different $(\mathrm{p}<0.05)$ by Duncan's multiple test (row). 


\section{Conflict of interests}

The authors declare no potential conflict of interest.

\section{ORCID}

Hee Nam Jung https://orcid.org/0000-0003-4236-5641

\section{References}

AACC. Approved Methods of the AACC. American Association of Cereal Chemists. St. Paul, MN, USA (2000)

An HK, Cho SG, Hong GJ. The characteristics of sponge cake added with Suaeda asparagoides. Culi Sci Hos Res, 22, 1-10 (2016)

AOAC. Official Method of the Analysis of AOAC Intl. 15th ed. Association of Official Analytical Chemists, Washington DC, USA, p 788 (1990)

Cha SS, Lee JJ. Quality characteristics and antioxidant activities of cookies added with Penceddanum japonicom Thunb powder. Korean J Hum Ecol, 25, 595-606 (2016)

Cho KR. Quality characteristics of sponge cake added with leek (Allium tuberosum Rottler) powder. Korean J Food Nutr, 23, 478-484 (2010)

Choi GY, Bae JH, Han GJ. The quality characteristics of sponge cake containing a functional and natural product (1. mulberry leaf powder). J East Soc Dietary Life, 17, 703-709 (2007)

Choi HI. The characteristics of sponge cake added with mugort powder. Culi Sci Hos Res, 22, 190-199 (2016)

Choi YH, Cho SS. Quality characteristics of Sulgidduk with different amount of dried Peucedanum japonicum powder. Culi Sci Hos Res, 24, 67-75 (2018)

Chung YS, Kim DJ. Quality characteristics of sponge cake with pakchoi (Brassica compestris L. ssp. chinensis Jusl.) powder. J Korean Soc Food Sci Nutr, 38, 914-919 (2009)

Gomez M, Ruiz-Paris E, Oliete B, Pando V. Modeling of texture evolution of cakes during storage. J Texture Stud, 41, 17-33 (2010)

Jang NH, Roh HS, Kang ST. Quality characteristics of sponge cake made with aronia powder. Korean J Food Sci Technol, 50, 69-75 (2018)

Jang Y, Song KY, O HB, Choi BB, Kim YS. Quality and antioxidant characteristics of sponge cake with asparagus (Asparagus officinals L.) powder. Korean J Food Cook Sci, 31, 642-651 (2015)
Ju T, Oh HS, Kim MJ, Kang ST. Quality characteristics of sponge cake with lemon grass powder. Korean J Food Sci Technol, 48, 347-353 (2016)

Jung HK, Jung WS, Ahn BK, Kang BM, Yeo JH, Cha SW, Park CG, Cho JH, Cho HW. Peucedanum japonicum Thunberg leaf alleviates the symptoms of dextran sulfate sodium induced ulcerative colitis in mice. Korean J Plant Res, 27, 421-428 (2014)

Kang SY, Oh TW, Kim JW, Park YK. Effect of the water extract of Peucedani japonici Radix on ovalbumininduced allergic asthma in mice. Kor J Herbology, 28, 1-7 (2013)

Kim DH, Han CS, Kim GE, Kim JH, Kim SG, Kim HK, Oh OJ, Hwang WK. Biolosical activities of isolated compounds from Peucedani Radix. Yakhak Hoeji, 53, 130-137 (2009)

Kim MK, Lee EJ, Kim KH. Effects of Helianthus tuberosus powder on the quality characteristics and antioxidant activity of rice sponge cakes. Korean J Food Culture, 29, 195-204 (2014)

Kim SY, Kim KJ. Quality characteristics and antioxidant activity of sponge cake with cabbage powder. Korean J Food Preserv, 24, 294-302 (2017)

Kim YA. Effects of mulberry leaves powders on the quality characteristics of yellow layer cakes. Korean J Food Sci Technol, 35, 871-876 (2003)

Lee JH, Kwak EJ, Kim JS, Lee YS. Quality characteristics of sponge cake added with Mesangi (Capsosiphon fulvescens) powder. Korean J Food Cookery Sci, 23, 83-89 (2007)

Lee JS, Seong YB, Jeong BY, Yoon SJ, Lee IS, Jeong YH. Quality characteristics of sponge cake with black garlic powder added. J Korean Soc Food Sci Nutr, 38, 1222-1228 (2009)

Lee MJ, Hwang ES. Quality characteristics and antioxidant activity of rice sponge cake with added green tea powder. Korean J Food Sci Technol, 48, 354-360 (2016)

Lee SE, Lee JH. Quality and antioxidant properties of sponge cakes incorporated with pine leaf powder. Korean J Food Sci Technol, 45, 53-58 (2013)

Lee WH, Yoo SS, Hong KW. Quality characteristics of Yanggaeng with Peucedanum japonicum powder. Culi Sci Hos Res, 24, 114-121 (2018)

Lim EJ. Quality characteristics of sponge cake added with Laminaria japonia powder. Korean J Food Nutr, 25, 922-929 (2012) 
O HB, Choi BB, Kim YS. Quality and antioxidant properties of sponge cake containing radicchio (Cichorium intybus L.) powder. Korean J Food Nutr, 28, 910-917 (2015)

O HB, Jung KY, Shin SY, Kim YS. Quality properties of sponge cake containing Dangyuja (Citrus grandis Osbeck) powder. Culi Sci Hos Res, 23, 83-89 (2017)

Onyango C, Mutungi C, Unbehend G, Lindhauer MG. Rheological and baking characteristics of batter and bread prepared from pregelatinised cassava starch and sorghum and modified using microbial transglutaminase. J Food Eng, 97, 465-470 (2010)

Park BG, Lee SY, Lee MH. Quality and antioxidant properties of sponge cake added with flaxseed powder. Culi Sci Hos Res, 23, 207-215 (2017)

Park JE, Jeong HD, Jang MS. Optimization of ingredient mixing ratio for preparation of sponge cake with bamboo (Pseudosasa japonica Makino) leaves powder. Korean J Food Cookery Sci, 25, 317-329 (2009)

Park JY, Park YS, Chang HG. Quality characteristics of sponge cake supplemented with soy fiber flour. Korean J Food Sci Technol, 40, 412-418 (2008)

Park YR, Han IJ, Kim MY, Choi SH, Shin DW, Chun SS. Quality characteristics of sponge cake prepared with red ginseng marc powder. Korean J Food Cookery Sci, 24, 236-242 (2008)

Seo EO, Ko SH, Jeong HC. Research quality characteristics of sponge cake added with red ginseng powder. Korean J Culi Res, 21, 130-140 (2015)

Shin GM. Quality characteristics of Lycii fructus powder added sponge cake. Korean J Culi Res, 21, 63-75 (2015) Shin JH, Choi DJ, Kwon OC. The quality characteristics of sponge cake with added steamed garlic powder. Korean J Food Cookery Sci, 23, 692-702 (2007)

Son HK, Kang ST, Jung HO, Lee JJ. Changes in physicochemical properties of Peucedanum japonicum Thunb. after blanching. Korean J Food Preserv, 20, 628-635 (2013)

Son HK, Kang ST, Lee JJ. Effects of Peucedanum japonicum Thunb. on lipid metabolism and antioxidative activities in rats fed a high-fat/high-cholesterol diet. J Korean Soc Food Sci Nutr, 43, 641-649 (2014)

Song KY, O H, Joung KY, Shin SY, Kim YS. Effects of basil (Ocimum basilicum L.) seed mucilage substituted for fat source in sponge cake: Physicochemical, structural, and retrogradation properties. Ital J Food Sci, 29, 681-696 (2017)

Song YK. Quality characteristics of sponge cake with added lotus leaf powder. Korean J Food Culture, 28, 651-656 (2013)

Yi SY, Kim CS, Song YS, Park JH. Studies on the quality characteristics of sponge cakes with addition of yam powders. J Korean Soc Food Sci Nutr, 30, 48-55 (2001) Zhang Y, Song KY, OH, Joung KY, Shin SY, Kim YS. Effect of pomegranate (Punica granatum L.) peel powder on the quality characteristics, retrogradation and antioxidant activities of sponge cake. Korean J Food Nutr, 30, 578-590 (2017) 